\title{
Post Authorization Safety Study Indicator
}

National Cancer Institute

\section{Source}

National Cancer Institute. Post Authorization Safety Study Indicator. NCI Thesaurus.

Code C139275.

An indication as to whether the clinical study is a post authorization safety study. 